\title{
PEMBERDAYAAN MASYARAKAT DAN PENGEMBANGAN POTENSI KEARIFAN LOKAL BERBASIS TEKNOLOGI TEPAT GUNA DI DESA KESIUT KECAMATAN KERAMBITAN KABUPATEN TABANAN
}

\author{
I.M. Merdana ${ }^{1}$ dan N.L. Watiniasih ${ }^{2}$
}

\begin{abstract}
ABSTRAK
Desa Kesiut sebagai Kawasan Pedesaan Prioritas Nasional (KPPN), menyimpan sumber daya dan kearifan lokal desa meliputi bidang pertanian, perkebunan, peternakan, perikanan dan industri rumahan. Berbagai program bantuan usaha ekonomi kreatif dilaporkan cukup efektif meningkatkan kesempatan kerja dan pendapatan rumah tangga miskin di Kecamatan Kerambitan. Kegiatan KKN PPM di Desa Kesiut bertujuan untuk pemberdayaan masyarakat dan pengembangan sumber daya kearifan lokal yang ada di desa melalui program kerja pokok. Metode penyelesaian program kerja pokok meliputi; (1) penyuluhan peningkatan produktivitas ternak babi dan sapi, (2) pelatihan inseminasi buatan pada ayam buras, (3) penyuluhan budidaya ikan air tawar dan pembuatan pakan ikan alternatif, (4) pelatihan biochast, (5) pelatihan pembuatan pupuk organik dan pestisida alami, (6) penyuluhan pengendalian hama pengganggu tanaman, (7) peningkatan produksi dan diversifikasi produk olahan pertanian serta pemasaran pasca panen. Melalui kegiatan KKNPPM Universitas Udayana Tahun 2018 di Desa Kesiut, telah dilaksanakan pemberdayaan masyarakat yang partisipatif dan upaya pengembangan potensi lokal desa.
\end{abstract}

Kata kunci : KKN PPM, desa kesiut, pemberdayaan, penyuluhan, pelatihan

\begin{abstract}
Kesiut village as a national priority rural area, have a resources and potential local wisdom covering the fields of agriculture, plantations, livestock, fisheries and home industries. Various creative economic business assistance programs are reported to be effective in increasing the income of poor households in Kerambitan District. The KKN PPM program in Kesiut Village aims to empower the community and develop existing local wisdom resources through the main work program. Methods of completing the basic work program include; (1) counseling on increasing productivity of pigs and cattle, (2) training on artificial insemination in domestic chickens, (3) extension of freshwater fish farming and making alternative fish feeds, (4) biochast training, (5) training in making organic fertilizers and pesticides natural, (6) counseling to control pest and plant disturbance, (7) increasing production and diversification of processed agricultural products and postharvest marketing. Through the Udayana University KKN-PPM program in 2018 in Kesiut Village, participatory community empowerment and local village potential development have been carried out.
\end{abstract}

Keywords: KKN PPM, kesiut village, empowerment, counseling, training

\footnotetext{
${ }^{1}$ Dosen Fakultas Kedokteran Hewan Universitas Udayana,imade_merdana@unud.ac.id

${ }^{2}$ Dosen Jurusan Biologi Fakultas MIPA Universitas Udayana,watiniasih@unud.ac.id
} 


\section{PENDAHULUAN}

Desa Kesiut termasuk sebagai Kawasan Pedesaan Prioritas Nasional (KPPN), dengan penduduk desa yang paling banyak rumah tangga miskinnya di Kecamatan Kerambitan, Kabupaten Tabanan, Bali. Secara geografis merupakan dataran rendah memiliki luas $266 \mathrm{~km}^{2}$ (266 Ha), secara administratif terbagi atas 5 (lima) dusun yaitu Banjar Kangin, Banjar Tengah Kaja, Banjar Tengah Kelod, Banjar Kawan Kaja dan Banjar Kawan Kelod. Jumlah penduduk 688 kk (2.203 jiwa), sebagian besar mata pencaharian utama dalam bidang pertanian, perkebunan, peternakan dan industri rumahan dengan penghasilan keluarga Rp.900.000-Rp.2.500.000 per bulan.

Berbagai program bantuan usaha ekonomi kreatif dilaporkan cukup efektif meningkatkan kesempatan kerja dan pendapatan rumah tangga miskin di Kecamatan Kerambitan (Wirawan, 2015). Kearifan lokal yang bisa dikembangkan antara lain bidang pertanian, peternakan, perikanan, industri rumah tangga, dasawisma dan kelompok masyarakat serta kehidupan sosial budaya masyarakat setempat. Pada bidang pertanian, memiliki luas sawah setengah kering $169 \mathrm{Ha}$, lahan kering $32 \mathrm{Ha}$ dan perkebunan $62 \mathrm{Ha}$. Sebagian besar masyarakat mengantungkan hidup sebagai petani, yang mana sangat didukung oleh kondisi lahan yang subur dengan sumber pengairan yang melimpah. Pertanian yang dimaksud meliputi persawahan dan hortikultura khususnya sayuran musiman secara tumpang sari. Dalam bidang peternakan tercatat ratusan penduduk sebagai peternak dengan rincian 300-an orang peternak sapi, 300-an orang peternak babi, 200-an orang peternak ayam buras, 10 orang peternak ayam ras dan juga peternak itik. Selain itu terdapat pula kelompok masyarakat yang bergerak dalam budidaya ikan, kelompok pengolahan produk pangan dan industri rumahan.

Pemberdayaan masyarakat partisipatif yang baik melibatkan seluruh komponen masyarakat lokal dalam semua tahap pembangunan (Adimiharja dan Hikmat, 2004). Strategi ini mengutamakan pentingnya peningkatan kapasitas masyarakat untuk kemandirian kekuatan internal dalam kontrol pengelolaan sumber daya yang ada berdasarkan kearifan lokal. Pembangunan jangka panjang yang berpusat pada rakyat lebih menekankan pada pemberdayaan, yang memandang inisiatif dan kreativitas dari rakyat sebagai sumber daya utama dalam pembangunan desa. Melalui program KKN-PPM Universitas Udayana di Desa Kesiut, diharapkan pemberdayaan masyarakat melalui program kerja yang terencana dapat menjadikan masyarakat yang mandiri dan memiliki motivasi diri, jiwa kewirausahaan sehingga berimbas pada peningkatan pendapatan, taraf hidup dan kesejahteraan, khususnya rumah tangga miskin.

\section{METODE PELAKSANAAN}

Persiapan dimulai dengan perencanaan survey lapangan, bertujuan untuk dapat mengidentifikasi permasalahan yang ada dan menggali potensi baru yang bisa dikembangkan. Audensi kepada Kepala Desa, tokoh masyarakat, kelompok tani, dan pelaku industri rumahan. Pada tahap ini juga dilakukan audensi kepada instansi-instansi terkait, proses perijinan dan pencarian narasumber.

Dari identifikasi permasalahan dan skala prioritas dapat dibuat program kerja sebagai berikut;

1. Penyuluhan peningkatan produksi ternak babi, dilanjutkan dengan kontrol pencegahan penyakit parasiter dengan pemberian obat cacing (endoparasit) dan spraying (ektoparasit).

2. Penyuluhan kesehatan reproduksi ternak sapi, dilanjutkan dengan kontrol penyakit parasiter dengan pemberian obat cacing (endoparasit) dan spraying (ektoparasit).

3. Penyuluhan dan pelatihan peningkatan produksi ayam buras melalui inseminasi buatan.Penyuluhan peningkatan produksi pertanian hortikultura dan pengendalian Organisme Pengganggu Tanaman yang ramah lingkungan.

4. Penyuluhan dan pelatihan peningkatan nilai nutrisi pakan ternak melalui teknologi biochast. Kegiatan dengan mengundang kelompok-kelompok tani dan dipusatkan di Dusu Kawan Kaja. 
5. Pelatihan pengolahan dan pemanfaatan kotoran ternak menjadi pupuk organik dan biopestisida.

6. Penyuluhan peningkatan produksi dan diversifikasi produk olahan pangan berbahan dasar lokal, dengan tema "Hygiene dan Good Manufactoring Product".

7. Penyuluhan peningkatan produksi ikan air tawar dan latihan pembuatan pakan ikan dengan memanfaatkan limbah peternakan.

Pelaksanaan program kerja ini melibatkan 30 orang mahasiswa dari berbagai bidang disiplin ilmu di lingkungan Universitas Udayana dengan dua orang dosen pendamping lapangan. Kegiatan berupa penyuluhan dan pelatihan akan mendatangkan narasumber ahli dibidangnya.

\section{HASIL DAN PEMBHASAN}

\subsection{Penyuluhan peningkatan produksi ternak babi dan praktek pencegahan penyakit parasiter ternak babi}

Pelaksanaan penyuluhan dan bimbingan teknis peningkatan produksi ternak babi dilakasanakan pada 3 Agustus 2018, dengan menghadirkan narasumber Drh. I Made Merdana, MP dari FKH Unud. Kegiatan diikuti sekitar 50 orang peternak, bertujuan untuk meningkatkan pemahaman peternak dalam hal manajemen pemeliharan ternak babi yang menguntungkan. Peternak juga diberikan bimbingan teknis mengenai langkah pencegahan penyakit parasit dengan pemberian obat cacing, pemberian vitamin, program vaksinasi untuk meningkatkan kesehatan ternak babi. Babi yang sehat akan menghasilkan produktivitas yang optimal, dan berdampak pada keuntungan yang maksimal. Dokumentasi kegiatan penyuluhan seperti pada gambar 1.
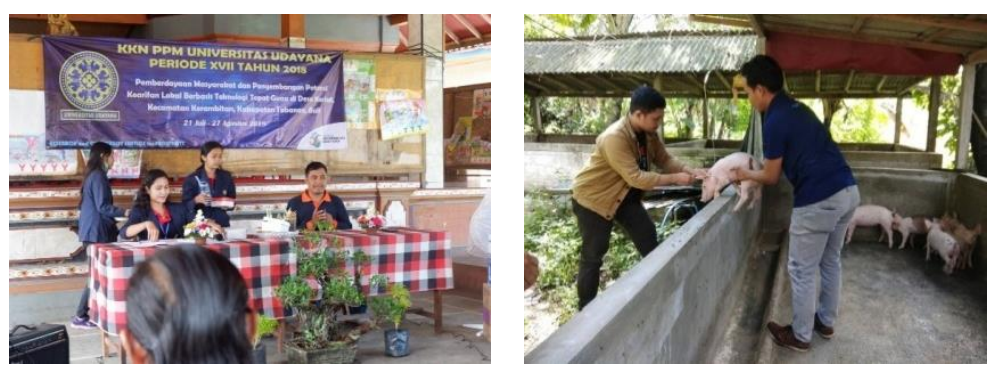

Gambar 1. Penyuluhan pemeliharaan ternak dan pelayanan kesehatan hewan

\subsection{Penyuluhan kesehatan reproduksi ternak sapi dan praktek kontrol penyakit parasiter}

Penyuluhan ini dilaksanakan di Balai Banjar Kesiut Kawan Kaja pada tanggal 4 Agustus 2018. Tujuan dari pelaksanaan program ini adalah untuk meningkatkan pengetahuan petani peternak dalam hal kesehatan reproduksi ternak sapi, dengan harapan angka kebuntingan dan populasi ternak sapi meningkat. Bimbingan teknis praktek pencegahan penyakit parasiter pada ternak sapi berupa pemberian obat cacing dan spaying kutu dan lalat. Pelatihan menghadirkan narasumber Dr. drh. I Wayan Sudira, M.Si, dari bagian Farmakologi FKH Unud. Kegiatan berjalan dengan baik dan sesuai jadwal dan terlihat antusias peternak dalam diskusi. Dokumentasi seperti pada gambar 2.

\subsection{Penyuluhan peningkatan produksi ayam buras melalui inseminasi buatan}

Penyuluhan dan pelatihan inseminasi buatan pada ayam buras telah dilaksanakan pada 7 Agustus 2018, dengan mengahadirkan narasumber Dr. drh. I Wayan Bebas, M.Kes dari Bagian Ilmu Reproduksi FKH Unud. Kegiatan yang diikuti sekitar 60 orang dari gabungan kelompok tani ternak berjalan dengan lancar dengan antusias peserta yang tinggi, seperti pada gambar 2. Dasar 
pemikiran dari pelaksanaan program ini adalah masih sedikitnya pengetahuan masyarakat yang belum mampu memanfaatkan potensi yang ada didesa kesiut ini, seperti melakukan inseminasi pada ayam buras, padahal potensi tersebut apabila bisa dikembangkan maka akan menjadi kelebihan tersendiri bagi peternak. Khusunya di Bali upacara keagamaan umat hindu yang selalu membutuhkan ayam pancawarna, akan tetapi ketersediaan ayam ini sangat terbatas. Untuk itu inseminasi buatan merupakan langkah tepat untuk pemecahan masalah tersebut.
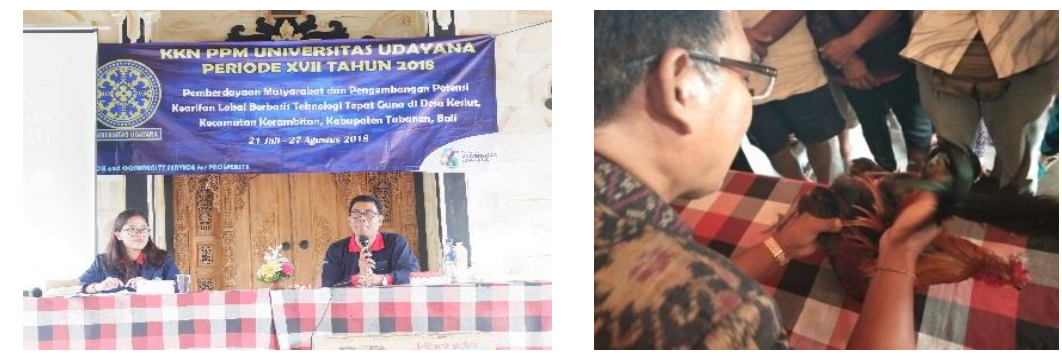

Gambar 2. Penyuluhan kesehatan ternak sapi dan pelatihan inseminasi buatan pada ayam buras

\subsection{Penyuluhan peningkatan produksi pertanian hortikultura, pengendalian organisme pengganggu tanaman yang ramah lingkungan}

Kegiatan ini dilaksanakan selama satu hari pada tanggal 9 Agustus 2018, dengan narasumber ahli pertanian Prof. Dr. Ir. I Made Sudana, MS dari FP Unud, dan diikuti 80 orang petani. Tujuan pelaksanaan program ini adalah untuk membantu petani meningkatankan produksi pertanian tanaman hortikultura, dan juga pencegahan terhadap organisme pengganggu tanaman yang ramah lingkungan. Keterampilan ini sangat diperlukan, mengingat Desa Kesiut memiliki basis pertanian hortikultura yang sangat baik dan memiliki potensi besar untuk ditingkatkan. Dalam penyuluhan petani diberikan pemahaman dan strategi meningkatkan produksi pertanian, dan juga langkahlangkah untuk mencegah organisme pengganggu tanaman. Kedepannya untuk menjaga pertanian yang sehat dan berkelanjutan harus kembali menggunakan produk yang organik dan alami, baik dalam hal pupuk dan pestisida.

\subsection{Pelatihan pengolahan kotoran ternak menjadi pupuk organik dan pestisida alami}

Bimbingan teknis pelatihan pembuatan pestisida alami dan produksi pupuk organik dari limbah kotoran ternak, merupakan kelanjutan dari pelatihan peningkatan produksi hortikultura dan penanggulangan OPT dengan pestisida alami diatas. Pelatihan ini dilakukan pada tanggal 9 Agustus 2018, diikuti oleh seluruh anggota kelompok tani. Produk yang dihasilkan dengan memanfaatkan limbah lokal yang dihasilkan oleh peternakan masyarakat setempat. Setelah kegiatan ini, petani diharapkan secara mandiri memproduksi pupuk dan biopestisida untuk menanggulangi hama tanaman hortikultura dengan efektif, sehingga efisiensi dalam produksi.
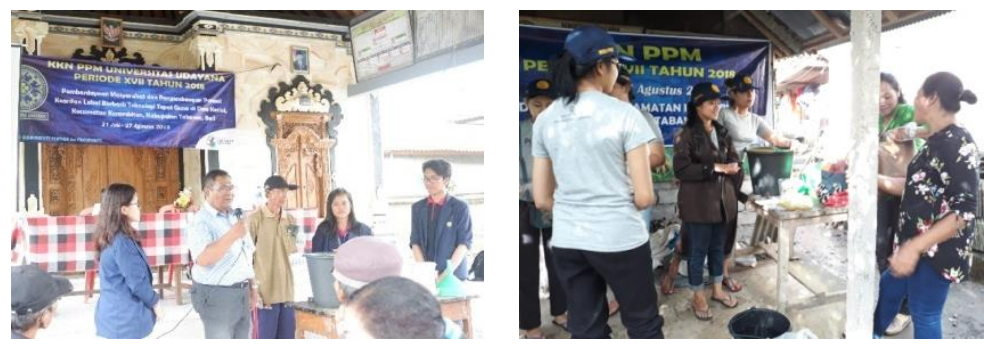

Gambar 3. Penyuluhan pertanian hortikultura dan bimtek pembuatan biourine dan pupuk organik

3.6. Penyuluhan dan pelatihan peningkatan nilai nutrisi pakan ternak melalui teknologi fermentasi 
Penyuluhan dan pelatihan peningkatan nutrisi pakan ternak melalui teknologi fermentasi dikenal juga dengan metode biochast. Tujuan dari penyuluhan ini adalah untuk menumbuhkan motivasi mayarakat petani dalam memanfaatkan limbah pertanian sebagai pakan yang bernutrisi untuk ternak sapi. Limbah yang digunakan pada bimtek ini adalah jerami padi dan juga bungkil kelapa. Kegiatan dilaksanakan pada 13 Agustus 2018 menghadirkan pembicara ahli dari Fakultas Peternakan Universitas Udayana yang dibantu asistennya, dengan mengundang 60 peserta dari anggota kelompok tani ternak dan juga kelompok wanita tani. Dengan harapan informasi menyebar lebih luas dan semakin banyak peternak yang mendapat pengetahuan.

\subsection{Penyuluhan pemanfaatan limbah pertanian sebagai pakan ikan alternatif}

Penyuluhan dan bimbingan teknis pembuatan pakan ikan alternatif dilaksnakan pada tanggal 15 Agustus 2018. Bimteks dengan menghadirkan penyuluh perikanan dari Kementerian Perikanan dan Kelautan yaitu I Made Sukmanada, SE., SSt.Pi. Kegiatan ini dilaksanakan di Gedung Serbaguna Desa Kesiut dandiikuti sekitar 40 petani ikan. Penyuluhan ini berhasil memberikan pengetahuan kepada petani ikan dalam hal memanfaatkan limbah pertanian dan peternakan untuk dijadikan pakan ikan alternatif. Hal ini dapat meningkatkan efisiensi produksi, mengingat harga pakan pabrikan terus naik. Keberhasilan transfer pengetahuan membuat petani ikan akan terhindar dari kerugian, karena tidak lagi bergantung $100 \%$ terhadap pakan pabrik.

\subsection{Penyuluhan dan Pelatihan Hygiene and Good Manufacturing Product, Diversifikasi Pangan Berbahan Dasar Lokal pada Industri Rumahan}

Pelatihan "Hygiene and Good Manufacturing Product", literasi keuangan serta diversifikasi produk olahan pangan berbahan dasar lokal ditujukan pada industri rumahan, kelompok dasawisma (ibu PKK) dan kelompok wanita tani. Program ini sukses dilaksanakan pada 10 Agustus 2018 di Balai Banjar Tengah kelod Desa Kesiut dan diikuti 68 peserta. Narasumber yang diundang ahli pangan Luh Trisna Darmayanti, S.Hut., M.P yang merupakan dosen Fakultas Teknologi Pertanian Unud. Program kerja ini bertujuan agar pelaku industri rumahan mampu meningkatkan produksi dari segi kualitas dan kuantitas.

Pengembangan produk olahan berbahan dasar lokal yang suskses dikerjakan yaitu produk Nugget Barong. Berbahan dasar sayuran bayam dan terong, dikarenakan dua jenis sayuran ini diproduksi dalam jumlah banyak di desa Kesiut. Harapanya dapat meningkatkan nilai jual dan menyerap kelebihan produksi. Peningkatan produksi dengan cara memberikan ilmu mengenai packaging yang bersih dan menarik.. Dalam pelakasanaan narasumber berbagi ilmu dan pengalaman mengenai pangan, cara pengemasan yang baik, dan cara berhitung mendapat keuntungan lebih banyak dari membuat produk olahan.
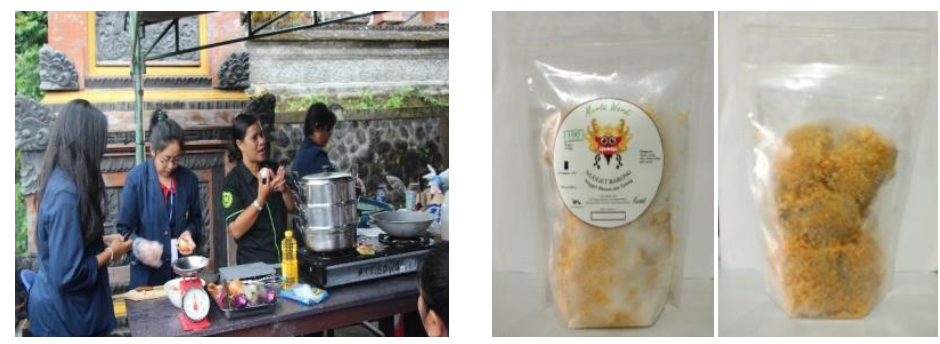

Gambar 4. Pelatihan diversifikasi produk olahan dan produk "Nugget Barong" yang telah dikemas

\section{KESIMPULAN DAN SARAN}


Melalui Program KKN PPM Universitas Udayana Tahun 2018 di Desa Kesiut, Kecamatan Kerambitan, Kabupaten Tabanan telah dilaksanakan pemberdayaan masyarakat dan pengembangan potensi lokal desa. Kegiatan yang berhasil dilakukan yaitu penyuluhan dan pelatihan peningkatan produksi dalam bidang pertanian, perkebunan, peternakan, perikanan, industri rumahan dan diverdifikasi produk olahan pangan berbahan dasar lokal.

Kegiatan pengabdian ini disarankan untuk bisa dilanjutkan dengan pengabdian masyarakat bentuk lainnya supaya bisa memberikan hasil yang maksimal sesuai yang diharapkan.

\section{UCAPAN TERIMA KASIH}

Penulis mengucapkan terima kasih kepada Direktorat Riset dan Pengabdian Masyarakat Dirjen Penguatan Riset dan Pengembangan Kemenristekdikti sesuai dengan Kontrak Pelaksanaan Program Pengabdian Kepada Masyarakat Nomor: 172.7/UN14.4.A/PM/2018, tanggal 19 Pebruari 2018 atas pendanaan Hibah KKN PPM. Penulis juga menyampaikan terimakasih kepada Rektor, Ketua LPPM dan Dekan Fakultas Kedokteran Hewan Universitas Udayana atas fasilitasi yang diberikan sehingga pengabdian kepada masyarakat terlaksana sesuai rencana.

\section{DAFTAR PUSTAKA}

Agung, O.A, I.N. T. Ariana, N.L.P. Sriyani, M. Dewantari Dan N.P. Sarini. 2015. Upaya Meningkatkan Produktifitas Sapi Bali Melalui Manipulasi Teknologi Pemberian Pakan Berbasis Hijauan. Denpasar. Universitas Udayana. https://simdos.unud.ac.id/uploads/file penelitian_1_dir/bd9688bc0d0fbc758cdac6fod6a399c7.pdf

Astawa, P.A, G. Mahardika, K. Budaarsa, K.M. Budiasa. 2013. Sosialisasi Pengolahan Pakan Dan Kotoran Ternak Dengan Teknologi Biofermentasi. Udayana Mengabdi (2) : 47-50.

BPS Kabupaten Tabanan. 2017. Badan Pusat Statistik Kabupaten Tabanan. https://tabanankab.bps.go.id/.

Budiono, B. 2002. Industri Kecil dalam Perspektif Budaya. Surabaya. Seminar Persfektif Industri Kecil Dalam Perkembangan Indonesia.

Buku Panduan Pelaksanaan Penelitian dan Pengabdian Kepada Masyarakat Edisi XI Tahun 2017.

Udjianto, A. dan R.D. Purnama. 2004. Inseminasi Buatan Pada Ayam Buras Dengan Metode Deposisi Intra Uterine. Bogor. Prosiding Temu Teknis Nasional Tenaga Fungsional Pertanian.

Wirawan, I.M.O, A. Zukhri, L.E. Tripalupi. 2015. Efektivitas Program Bantuan Usaha Ekonomi Produktif (Uep) Dalam Upaya Peningkatan Kesempatan Kerja Dan Pendapatan Rumah Tangga Miskin Di Kecamatan Kerambitan. http://ejournal.undiksha.ac.id/index.php/JJPE/article/view/5075. 